\title{
THE FIT BETWEEN EMPLOYEE ROLES AND MARKET DYNAMISM: AN ECOLOGICAL MANAGEMENT PERSPECTIVE
}

\author{
JACK P. CRIELAARD, EMIEL F. M. WUBBEN, AND ONNO S. W. F. OMTA \\ Wageningen University and Research
}

To cite this paper: Crielaard, J. P., Wubben, E. F. M., \& Omta, O. S. W. F. (2018). The fit between employee roles and market dynamism: An ecological management perspective. Revista de Administração Mackenzie, 19(2). doi:10.1590/1678-6971/eRAMR180114

Submission: Nov. 17, 2017. Acceptance: Jan. 03, 2018.

\section{(cc) BY} This is an open-access article distributed under the terms of the Creative Commons Attribution License.

\footnotetext{
This paper may be copied, distributed, displayed, transmitted or adapted if provided, in a clear and explicit way, the name of the journal, the edition, the year and the pages on which the paper was originally published, but not suggesting that RAM endorses paper reuse. This licensing term should be made explicit in cases of reuse or distribution to third parties. It is not allowed the use for commercial purposes.

Este artigo pode ser copiado, distribuído, exibido, transmitido ou adaptado desde que citados, de forma clara e explícita, o nome da revista, a edição, o ano e as páginas nas quais o artigo foi publicado originalmente, mas sem sugerir que a RAM endosse a reutilização do artigo. Esse termo de licenciamento deve ser explicitado para os casos de reutilização ou distribuição para terceiros. Não é permitido o uso para fins comerciais.
} 


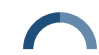

Jack P. Crielaard, Emiel F. M. Wubben, Onno S. W. F. Omta

\section{ABSTRACT}

Purpose: Exploring the fit of employee roles and market dynamism, related to performance.

Originality/value: In ecology the term 'fit' is used for the relation between organisms and their environment. Similarly, we conceptualized the relation between employee roles and markets: the employee-market connection, which may enhance SME's strategic fit and performance.

Design/methodology/approach: The empirical research was conducted at 48 SMEs with 221 respondents from the manufacturing industry $(53 \%)$ and the service industry $(47 \%)$ and applied a mixed model analysis.

Findings: The employee role-mix is moderated by market dynamism: when market dynamism increases, the impact on performance of internal process roles decreases and the impact of rational goal roles increases. The results enrich the resource-based view with the employee-marketconnection: the system is resilient, the roles adapt. A fit between market dynamism and employee roles is positively related to performance.

\section{KEYWORDS}

Strategic fit. Resource-based view. Market dynamism. Employee roles. Innovation. 


\section{INTRODUCTION}

Just as species in an ecosystem can flourish when they are adapted to the environment, employees in an organization can deliver high performance when their roles are adapted to the market. In this analogy a role is a behavioral pattern, with associated competences, to fulfill the demands of the market. When it fits, growth and production will lead to survival and reproduction of the trait (Stearns \& Hoekstra, 2005). In a similar conceptualization, the employee roles and related competences are adapted to the market. At an organizational level, this analogy implies that the employee community has to be connected to the market to attain a marketadapted role-mix. However, this connection between employees and markets has been neglected up to now in the debate about strategic fit between the neo-classical approach, or positioning school (Cyert \& March, 1963; Porter, 1985; Williamson, 1979), and the Resource-Based View (Barney, 1991; Wernerfelt, 1984)/dynamic capabilities view (Stalk, Evans, \& Shulman, 1992; Teece et al., 1997).

Both the positioning school and resource-based view (RBV) share the assumption that alignment between the firm and the outside world will enhance performance. What divides them is the way of achieving fit. Is it merely an outside-in approach, where business positioning and productmarket-combinations follow market developments (Ansoff, 1957; Porter, 1985; Treacy \& Wiersema, 1995), or is it an inside-out approach where organizational capabilities, defined as a firm's ability to perform a productive task (Grant, 1996), develop resource-product matrices and shape the market (Barney, 1991, 2001; Teece, Pisano, \& Shuen, 1997; Wernerfelt, 1984). Both take 'product' as a building block for alignment (product to market; resources to product).

The present study investigates the third possibility: In ecology the term 'fit' is used for the relation between organisms and environment, or in economic terms the direct relationship between resources and markets. Rather than analyzing firms from the product side, we explore the concept of 'employee-market connection'. This concept links community characteristics, like role-mix, and firm capabilities, like knowledge and innovativeness, with environmental characteristics like dynamism, hostility and complexity (Dess \& Beard, 1984; Luo \& Peng, 1999). The fit will be related to performance. The central research question of the present study is: will companies perform better, when there is a fit between the environment 
and the employee role-mix; and are firm capabilities indifferent to the environment? We analyze the influence of market dynamism in the relationship between human resources (role-mix), knowledge related firm capabilities and performance. The results will indicate how SMEs can enhance their strategic fit and performance.

This paper is structured as follows: section 2 elaborates on the theoretical background concerning the positioning/RBV debate and the ecological notion of fit between environment and competences. In section 3 , the research model will be presented with propositions about the influence of market dynamism on role-mix and firm capabilities related to performance. Section 4 describes the research methods and data analysis, and section 5 describes the results of multi-level analyses and conclusions. The implications for theoretical debate, business practice, and further research will be discussed in section 6 .

\section{AN ECOLOGICAL NOTION OF STRATEGIC FIT}

In the neo-classical market-based approach, represented by the positioning school (Porter, 1985), the market developments, the desired position in the market and the derived product-market combinations (Ohmae, 1982) direct the organizing of processes and systems, and the hiring of required personnel (counter clockwise in Figure 2.1). Processes in the value chain and decisions about the necessary resources follow deliberate strategic choices and are prescribed by the desired position. Competitive advantage is achieved by economic market power, but also by barriers or (political) power mechanisms (Mintzberg, Ahlstrand, \& Lampel, 1998). This presupposes the manageability of the organization and the assumption of achievable market positions. However, a gap between plan and realization might occur, implying a risk of dealing with apparent realities, misfit in moving markets, and ignoring effects of power behavior.

The increasingly technology driven economy and attention to innovation has opened up more resource based (Barney, 1991; Hamel \& Prahalad, 1994) or dynamic capability based (Stalk, Evans, \& Shulman, 1992; Teece et al., 1997) perspectives (clockwise direction in Figure 2.1). The strategic focus is on learning, competences and capabilities to develop distinctive resourceproduct-matrices from which new strategic options emerge. Organizational resources, like role-mix and firm capabilities, have to be valuable, rare, inimitable and non-substitutable/organized (VRIO), to create a valuable 
product or market proposition. The risk is the 'tautology of valuation': resources must be valuable to deliver a value proposition. The RBV presupposes that resources are not homogeneous nor perfectly mobile, making competitive advantage possible. Furthermore, causality remains a black box when resources are tacit and complex (Priem \& Butler, 2001a), and this might turn into a weakness or organizational inertia (Witteloostuijn, 1998) when the cause of resource-based advantage is not very well known and changing environments require adaptation.

Recent literature calls for further development of the RBV and the dynamic capabilities view (Kraaijenbrink, Spender, \& Groen, 2010; McWilliams \& Siegel, 2011). According to Hamel (2009) ecological perspectives might be useful in addressing the criticism on the RBV, adding an environmental demand model (Priem \& Butler, 2001a), or exploitation of the resource by another capability (Newbert, 2008). Research that focuses on the relation between resources and strategy implementation, or the fit between employees and market characteristics is under-developed (Armstrong \& Shimizu, 2007; Priem \& Butler, 2001b). Dealing simultaneously with resource-side issues and demand-side issues requires "solutions addressing core connections between resources and business environment" (Priem \& Butler, 2001b).

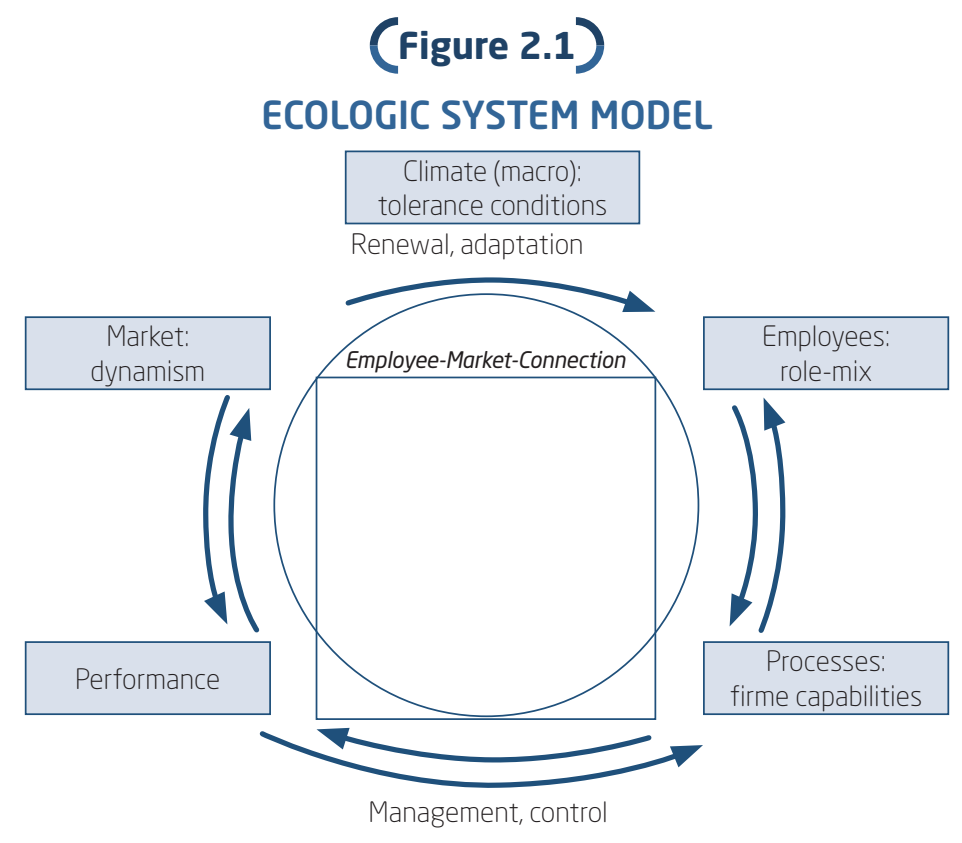

Source: Elaborated by the authors. 
In line with these statements, the ecologic system model presented in Figure 2.1 (Crielaard, 2008) demonstrates a supplementary concept: a fit between employee community and market (employee-market connection). Ecology deals with relationships between organisms and their living and non-living environments, that determine distribution and abundance of organisms (Begon, Harper, \& Townsend, 1996; Townsend, Harper, \& Begon, 2000). Fitness between organism and environment is defined as the average reproductive success of individuals with a certain trait, relative to the average fitness of individuals with another trait (Stearns \& Hoekstra, 2005) dependent on the conditions and external resources ${ }^{1}$ of the environment. When, in this analogy, an employee fits to the demands of the market, growth and production, it will lead to survival and reproduction of the role and related competences. At the organizational level this analogy implies a mix of roles and competences of the community, being this the outcome of the joint individual fits of roles and related competences with the market characteristics. The logical consequence is that when market characteristics change, the proportions of the individual fits or roles and related competences in the role-mix will change.

Venkatraman (1989) makes a distinction between six forms of fit, dependent on the presence of a criterion and the number of variables or the degree of specificity of the relationship. When there is no criterion, he distinguishes from many variables to few variables: fit as gestalts, fit as covariation and fit as matching. When there is a criterion, he distinguishes from a low to a high degree of specificity: fit as profile deviation, fit as mediation and fit as moderation. In the present study, with performance as a result criterion and a high degree of specified role variables, fit is taken as moderation, where market dynamism is the moderating factor.

Besides the joint individual roles and competences in the role-mix, we take the firm capabilities into account. These are the company's abilities to perform a productive task (Grant, 1996), which in the present study are restricted to knowledge and innovativeness. The present study investigates the fit between the resources' functionalities (employee role-mix and the firm capabilities) and market dynamism in pursuing performance. environment, being the energy or food used by individuals to live; in economy, human resources are the individuals themselves being a part of the organization, being the tools to produce. 


\section{RESEARCH MODEL AND PROPOSITIONS}

In this section we operationalize the ecologic system model in variables for market dynamism, role-mix, capabilities, and performance. After putting these variables in a research model we construct reasoning for consecutive propositions.

\subsection{Research model}

We build on ecological logic that species, with their functionalities, fit in appropriate environments or niches. Some niches are more favorable than others, resulting in better performance when the environment fits to the species. The environment in an ecosystem is characterized by three elements: temporal variation (unpredictability), climatic conditions (tolerance) and spatial heterogeneity (complexity) (Begon et al., 1996). The same elements can be found in management literature: temporal variation is found as dynamism (unpredictability), climatic condition as hostility (tolerance), and spatial heterogeneity as complexity (heterogeneity) (Dess \& Beard, 1984; Luo \& Peng, 1999). The measure of dynamism as formulated by Luo and Peng (1999), forms the market characteristic in the present study.

A common model to conceptualize individual roles and competences in organizations, as well as for the community, is the competing values framework (Cameron \& Quinn, 2011; Quinn, Faerman, Thompson, \& McGrath, 1990; Quinn \& Rohrbaugh, 1983). The competing values framework is a meta-model representing the main ideas, which have emerged over time and is often tested and applied (Kalliath, Bluedorn, \& Gillespie, 1999; König, Diehl, Tscherning, \& Helming, 2013; Patterson et al., 2005). It distinguishes between the dimensions of flexibility (oriented at decentralization and differentiation) versus control (oriented at centralization and integration), and internal (oriented to maintaining the system) versus external (orientated to competitive position of the system). These two axes result in four quadrants, containing competing values, and respective roles (Quinn et al., 1990):

- the Open System model values change and expansion, with innovator and broker roles, and competences like creative thinking, negotiating, present ideas;

- the Internal Process model values continuity and consolidation, with monitor and coordinator roles, and competences like project and cross 


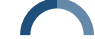

Jack P. Crielaard, Emiel F. M. Wubben, Onno S. W. F. Omta

functional management, information handling, measure and analyze, quality and performance;

- the Rational Goal model values maximization of output, with producer and director roles, and competences like productive work, create vision, set goals, and planning;

- the Human Relations model values development of human resources, with mentor and facilitator roles, and competences like team building and conflict management.

On the organization level the employee community is characterized by the role-mix (Cameron \& Quinn, 2011).

We define organizational capability as the company's ability to perform a productive task (Grant, 1996). Following Grant, integration of knowledge is the essence of an organizational capability, related to the firm's capacity to create value, based on the integration of knowledge of a number of individuals. To cope with increasing complex issues from a fast evolving environment, new knowledge is also proposed (Nonaka \& Von Krogh, 2009), which we operationalize as innovativeness.

Performance is measured by the perceived profit. Although the effects of the actvities of a company are felt much broader than only in financial results or products (Brundtland, 1987; Global Reporting Initiative, 2011; Parnell, 2008), we focused on profit.

The relations between the above mentioned variables are pictured in the research model in Figure 3.1.1. The direct relations to performance are presented as solid lines. The dotted lines represent fit as moderated by market dynamism to test the change in the direct relations between rolemix and performance, and between capabilities and performance under the influence of market dynamism. The numbers refer to the propositions in paragraph 3.2. 


\section{(Figure 3.1.1)}

RESEARCH MODEL: DOTTED LINE IS MODERATION TO TEST FIT

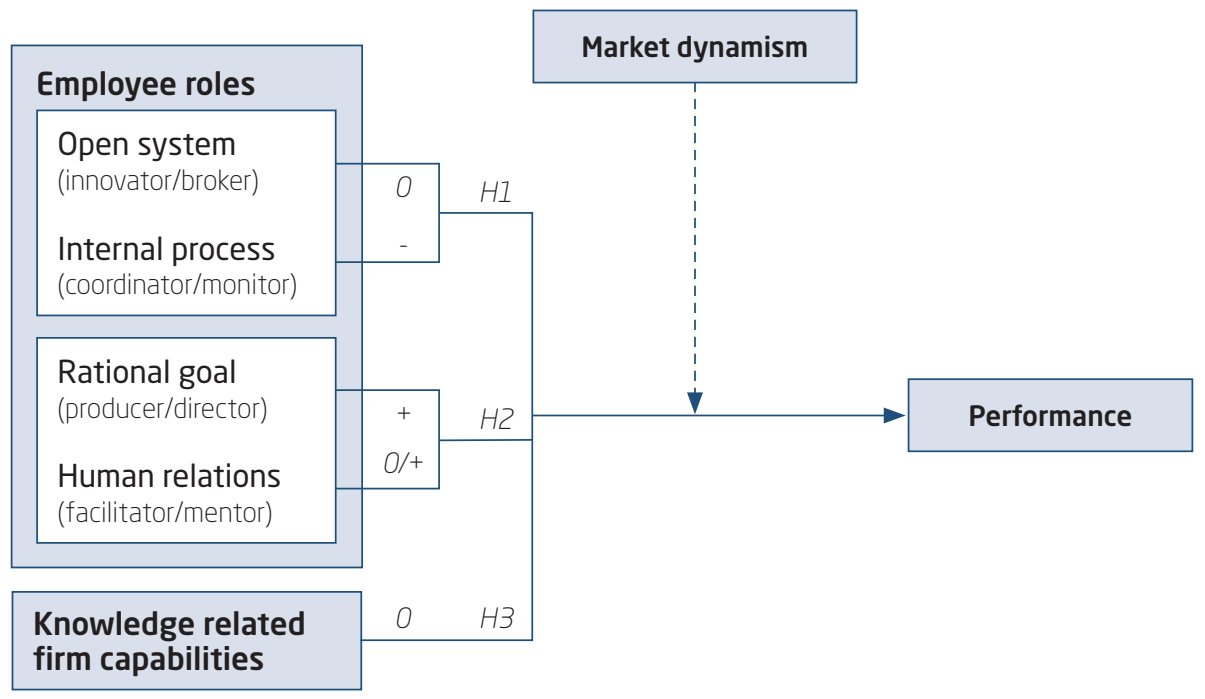

Source: Elaborated by the authors.

\subsection{Explorative propositions}

The propositions in this article have to be seen as expectations, because of the explorative character of the research. Propositions 1 and 2 deal with the strategic fit between employees and market dynamism: the moderation of the role-mix by market dynamism. Proposition 3 deals with the indifferent relationship of knowledge related firm capabilities and market dynamism.

The first proposition investigates the relative change in roles on the open system - internal control axis. According to Quinn (1990), every role will contribute and all types are needed in an organization, but the role-mix may change depending on external and internal factors. The neo-classical outside-in approach prevents unpredictability, and therefore having more control, by a strategy process of combating industry forces (Porter, 2008). Also, as a part of the strategy process, management often brings in more open system roles when dynamism increases. However, this is not a direct relationship between market dynamism and role-mix, but the effect of a deliberate strategy process, following the counter clockwise direction in Figure 2.1.

Otherwise, according to the RBV, the need for innovative and flexible organizational capabilities will be higher in a highly dynamic environment 
(Gunderson \& Holling, 2002; Ketkar \& Sett, 2010; Lawrence \& Lorsch, 1967; Mintzberg et al., 1998; Volberda, 1992). Organizations directed to innovation, new products and services, emerging markets, and co-creation embrace more exploratory behaviors (March, 1991), probably neglecting exploitative processes, like refinement and replication, needed for incremental innovation in more stable circumstances of growth and maturation (Benner \& Tushman, 2003; Hannah \& Lester, 2009; Williams, 1998). Research on strategic leadership shows that different leadership behaviors are necessary to support exploration or exploitation (Jansen, Vera, \& Crossan, 2009; Lawrence, Lenk, \& Quinn, 2009): transformational leadership (Bass, 1985) stimulates innovation and creativity and transactional leadership fosters reward for the planned effort and management by exception to take remedial actions when needed (Avolio, Bass, \& Jung, 1999). Both, neoclassical approach and RBV, suggest an increase in open system roles when market dynamism augments.

However, in an ecosystem, the abundance, performance and interaction of a group of individuals are at stake, which entails other reasoning. Flexible types (open system roles) have a wider tolerance range against irregular disturbances and can exist in more niches (Mackenzie, Ball, \& Virdee, 1998); those will not directly decrease when dynamism increases. It is just that the inflexible types only exist in places within their limited range of tolerance. Likewise, too much attention to the internal planning process, policy and procedures, or control and process analysis will lead organizations astray from market activities (Mintzberg, 1983). Following an ecologic model we deduct that when market dynamism increases, the performance of flexible open system types will stay the same, but in the role-mix the internal process roles will ebb.

Hypothesis 1: When market dynamism increases, there will be a better performance when in the role-mix the internal process roles decrease and the proportion of open system roles remains constant.

The second proposition investigates the relative change in roles on the axis rational goal - human relations. Result orientation can be useful in both exploration as well as in exploitation, provided that it is an external orientation (Jansen et al., 2009). A dynamic environment stresses the need for cost-efficiency and higher productivity (Volberda, 1992). When competition increases and markets become more demanding, rational goal competences will help to occupy niches quick and with enough mass (Quinn et al., 1990). This corresponds to what happens in pioneer (dynamic) 
ecosystems: occupying niches quick and with much mass. Besides these rational goal roles, researchers also indicate a better performance and a high performing organization when there is more attention to the human factor in organizations, human relations and empowerment (Gratton, 2000; Pfeffer, 1998; Verkerk, 2004), combined with values like social justice (Castells, 2002), or sustainability (Crielaard, 2008). Strategic HRM supports both performance management and the social context (Raisch \& Birkinshaw, 2008), in order to enhance organizational flexibility and resilience in fast changing conditions (Cooper, Liu, \& Tarba, 2014; Ketkar \& Sett, 2010; Lengnick-Hall, Beck, \& Lengnick-Hall, 2011). However, in an ecosystem, the relation roles are the structure of the system itself; the interplay between organisms and environment supports the resilience of the system. In an unpredictable environment, ecosystems are resilient and will persist when there is a simple structure (low spatial heterogeneity), dynamical robustness (high flexibility) and strong or direct connections with the environment and perturbations (Mackenzie et al., 1998). Therefore, we deduct that the change in the proportion of human relation roles when market dynamism increases will be a derivative of open system roles and rational goal roles. It can be expected that when market dynamism increases the rational goal roles, which enhance productivity, will augment. Also, it can be expected that human relation roles, which support flexibility, productivity and resilience dependent on the environment, will augment with increasing market dynamism, albeit a derivative.

Hypothesis 2: When market dynamism increases, there will be a better performance when in the role-mix the rational goal roles and the human relation roles.

The third proposition is about knowledge related firm capabilities. Neoclassical strategists put forward that organizations have to respond to the market. Organizations have to adapt their capabilities to the dynamics of the market by a deliberate strategy process. From this point of view the relationship between capabilities and performance will be moderated by market dynamism.

On the contrary, if firm capabilities are the starting point for strategy, market dynamism will have no influence on capabilities. Organizations mute the influence of the market and exclude the dynamism of the market, according to the law of requisite variety (Ashby, 1956). There is a certain resistance and resilience (Holling, 1973) of the system towards disturbances, for instance, built by the collective capabilities which can absorb, process 
and repair the effects of disturbances and maintain the system (Gunderson \& Holling, 2002). Furthermore, companies construct resource-product matrices, based on capabilities and, in doing so, they shape the market (Wernerfelt, 1984). Hypothesis 3 follows this capabilities point of view.

Hypothesis 3: Market dynamism will have no influence on the relationship between knowledge related firm capabilities and performance.

\section{METHODS}

\subsection{Data collection}

The unit of analysis is the individual within an independent operating unit, thus an SME or an autonomous subsidiary belonging to a bigger organization. The empirical research was conducted in Netherlands at 48 business organizations, with 221 respondents, in a variety of branches with varying levels of dynamism to observe a wide range of environments and organizations (Jansen et al., 2009). Non-response bias was prevented by a convenience sample with sufficient variation. To deal with inter-observer reliability and potential common method bias, the questionnaires were separated and collected from multiple respondents per organization by independent persons. Based on research requirements (Field, 2009), the number of respondents per organization ranged from 3 to 6 with an arithmetic mean of 4.6 per organization, so organizations weighed the same in the dataset. Labor intensive attendance of students resulted in a response rate of $95 \%$. To assure confidentiality, names of respondents and organizations were not revealed. In return, every organization received a full report of their scores in relation to the mean scores with comments and dedicated advice about possible management measures.

\subsection{Measurement and validation}

The research uses a cross-sectional design. In order to test the model empirically, the factors derived from literature were operationalized in a survey questionnaire and pretested separately, using existing scales from respective research. Because hard data in SME's are not always available, we used the respondents' perception in a seven-point Likert scale from 1-7. Factor analysis confirmed the constructs. In our dataset the reliability of the 
Quinn roles has a Cronbach $\alpha$ between.76 and.91. For market dynamism the items from Luo and Peng (1999) were refined according to the factor analyses (Cronbach $\alpha .69$ ). The dependent variable performance was measured as perceived profit performance (Cronbach $\alpha .79$ ). The construct for capabilities consists of perceived results on knowledge and innovativeness (Cronbach $\alpha .74$ ). The research variables, definitions and measurement, means, standard deviations and Cronbach $\alpha$ are specified in Appendix 1.

\subsection{Methods of data analysis}

We controlled for categorical influences by taking the company on a higher hierarchical level in a mixed model analysis. The covariance structure is not clear beforehand, so we took consecutive steps to build up models in order to compare the explaining power of the models (Field, 2009). The explaining power was tested by a Chi-square statistic and represented by the -2 Log Likelihood (-2LL). Firstly, we added random intercepts to the model and, secondly, we added random slopes in the mixed model regression analyses. Covariance mainly occurred concerning the intercepts, not in relation to the estimates. In other words, the company as a variable causes a significant variability in the constant (the intercept) factor, but no significant variability in the estimate (the slope).

Capabilities and competences are not analyzed together, because of mutual dependency. To test fit, we introduced interaction terms in a second step. In line with Venkatraman (1989), we took moderation as the interaction effect, because the research model has a clearly set out number of variables and specific selection criteria.

\section{ANALYSIS AND RESULTS}

The empirical research was conducted in the Netherlands at 48 SMEs, with 221 respondents. The respondents had commercial jobs (20\%), operational jobs (53\%), support jobs (16\%), and control/administrative jobs $(11 \%)$, divided in managerial level $(48 \%)$ and employee level $(52 \%)$. The researched entities are part of the manufacturing-industry (53\%) and service-industry (47\%). The (arithmetic) mean size of the organization in this convenience sample was 296 full-time employees ( $s d=364 ; 30-660)$. All companies are an independent operating unit. 


\subsection{Moderation of roles by market dynamism}

Table 5.1.1 shows the influence of dynamism and roles on the dependent variable performance, controlled for company influence by a mixed model analysis (Field, 2009). The company influence is shown to be important, which is reflected in the significance of the intercept in Table 5.1.1. Both, factoring in a mixed model structure (the intercept), and bringing in the interaction (model 2), are a major significant improvement of the model ${ }^{2}$.

The influence of the Internal Process role $(0,23 ; p<0,10)$ on the changeconsolidation axis is significant and the Open System role $(0,20 ; p=0,11)$ is a best linear unbiased estimate. When dynamism increases, the estimate of the product score with the Open System roles is not significant $(-0,08$; $\mathrm{p}=0,33)$; the product score of the Internal Process role shows a significant negative value $(-0,18 ; p<0,05)$, which indicates a substantial inhibition of the contribution.

On the task - human relations axis, dynamism enhances the contribution of Rational Goal roles significantly (product score 0,15; p $<0,1$ ) and shows a best linear unbiased estimate for Human Relations roles (product score 0,$11 ; \mathrm{p}=0,13$ ). Concerning performance, hypothesis 1 (a decrease of internal process roles and no change in open system roles when market dynamism increases) and hypothesis 2 (increase of rational goal roles and human relations roles when market dynamism increases) are supported.

(Table 5.1.1)

ESTIMATES OF FIXED EFFECTS BY DYNAMISM AND ROLES

\begin{tabular}{|c|c|c|}
\hline Parameter & Model 1 & Model 2 \\
\hline Intercept & $2.02^{\star * \star}$ & $2.18^{\star \star}$ \\
\hline Dynamísm & $-0,01$ & $-0,10$ \\
\hline Open System & 0,20 & $0,39^{1}$ \\
\hline
\end{tabular}

(continue)

2 Factoring in a hierarchical mixed model structure results for profit in a highly significant better model $(-2 \mathrm{LL}=656)$ compared to when the hierarchical structure is not taken into account (similar to an Ancova/regression; -2LL $=686)$. With a change in degrees of freedom of 1 , for which the critical values for the chi-square statistic are $3,84(\mathrm{p}<.05)$ and $6,63(\mathrm{p}<.01)$, the chi-square change of $686-656=30, p<0,01$ is a major improvement of the model. Bringing in the interaction is also a significant improvement of the model $(\mathrm{df}=4,-2 \mathrm{LL}=646, \mathrm{p}<0,1)$. 


\section{(Table 5.1 .1 (conclusion))}

ESTIMATES OF FIXED EFFECTS BY DYNAMISM AND ROLES

\begin{tabular}{lll}
\hline \multicolumn{1}{c}{ Parameter } & Model 1 & Model 2 \\
\hline Rational Goal & 0,15 & $-0,16$ \\
\hline Internai Process & $0,23^{*}$ & $0,64^{\star *}$ \\
\hline Human Relations & $-0,01$ & $-0,29$ \\
\hline Dynamísm * Open system & & $-0,08$ \\
\hline Dynamísm * Rational Goal & & $0,15^{\star}$ \\
\hline Dynamísm * Internai Process & $-0,18^{\star \star}$ \\
\hline Dvnamísm * Human Relations & 0,11 \\
\hline Intercept variance (subject = firm) & $0,45^{\star \star}$ & $0,46^{\star \star}$ \\
\hline
\end{tabular}

$\mathrm{n}=196$ at48 SMEs; ${ }^{1} p<1 ;{ }^{*} p<05 ;{ }^{* \star} p<01 ;{ }^{* \star \star} \mathrm{p}<001$

Dependent variable: Performance: Profit.

Source: Elaborated by the authors.

Beside profit as performance variable we also took a quick view at People and Planet as performance variables. The performance variable People (societal) shows the same tendency as Profit, with some interesting differences. Here the intercept is not significant $(0,67 ; p=0,30)$, and concerning the interaction effect of market dynamism on the role-mix, only the product score of Dynamism with Rational Goal shows a best linear unbiased estimation and might be economically relevant (product score $0,13 ; p=0,11)$. Concerning the performance-variable Planet, only the intercept is significant.

\subsection{Moderation of knowledge related firm capabilities by dynamism}

Model 3 in Table 5.2.1 shows a large significant direct effect of knowledge related firm capabilities on performance $(0,48, \mathrm{p}<0.001)$. As predicted by Hypothesis 3 dynamism does not moderate the contribution of capabilities (Model 4, product score $-0,03 ; p=0,69)^{3}$. A closer look at the different

3 Bringing in the interaction in model $2(-2 \mathrm{LL}=667)$ does not improve model $1(-2 \mathrm{LL}=668)$, according to hypothesis 3. 
performance measures results in the same conclusions for Profit, People and Planet. For the three output criteria, Hypothesis 3 is supported.

The performance variable People (societal) may indicate another latent effect. For this performance criterion the intercept is not significant and there is an indication of a moderating effect by dynamism (product score $=-0,077$; $\mathrm{p}=0,16)$.

(Table 5.2.1)

ESTIMATES OF FIXED EFFECTS BY DYNAMISM AND CAPABILITIES

\begin{tabular}{lll}
\multicolumn{1}{c}{ Parameter } & Model 3 & Model 4 \\
\hline Intercept & $2.44^{\star \star *}$ & $2.21^{\star *}$ \\
\hline Dynamism & $-0,03$ & 0,06 \\
\hline Knowledge relate d firm capabilities & $0,48^{\star \star \star}$ & $0,56^{\star}$ \\
\hline Dynamism * Capabilities & & $-0,03$ \\
\hline Intercept variance $($ subject $=$ firm) & $0,42^{\star \star}$ & $0,42^{\star \star}$ \\
\hline
\end{tabular}

$\mathrm{n}=196$ at48 SMEs; ${ }^{1} \mathrm{p}<1 ;{ }^{*} \mathrm{p}<05 ;{ }^{* \star} \mathrm{p}<01 ;{ }^{* \star *} \mathrm{p}<001$.

Dependent variable: Performance: Profit.

Source: Elaborated by the authors.

Figure 5.2.1 summarizes the findings: there is moderation by market dynamism of the relationship between role-mix and the performance criterion Profit. Furthermore, this research found no moderation by market dynamism of the relationship between knowledge related firm capabilities and performance. 


\section{(Figure 5.2.1)}

\section{SUMMARY OF RESULTS}

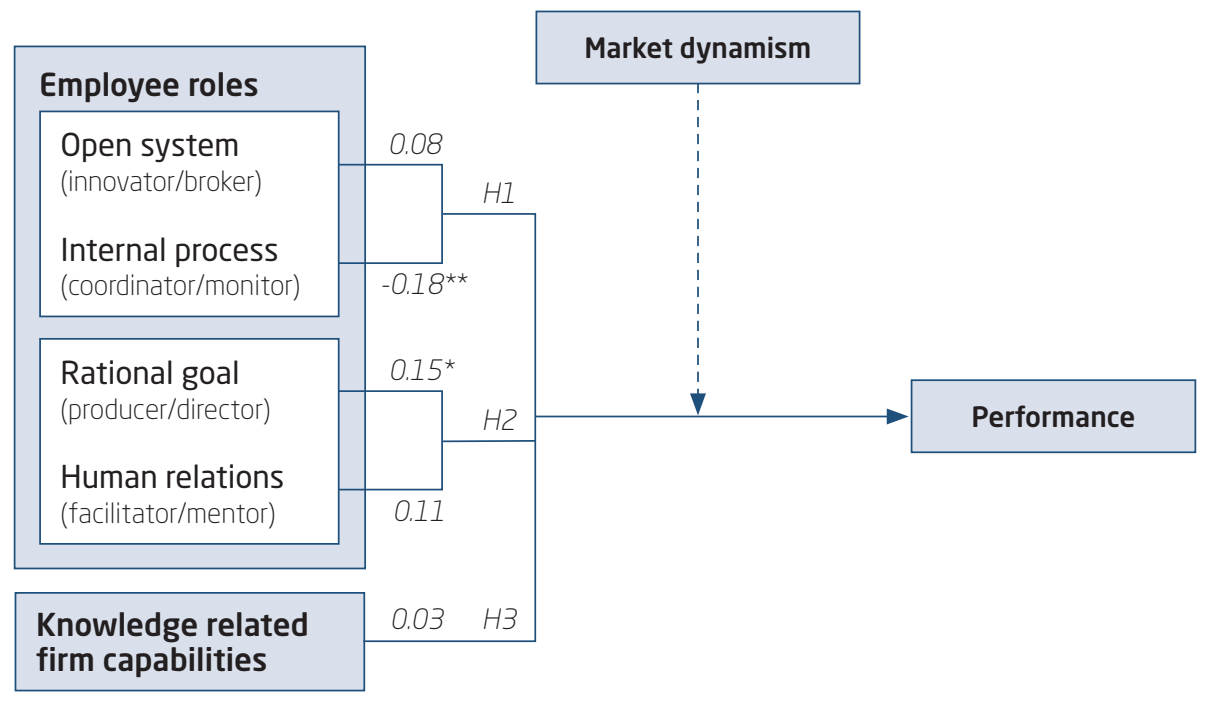

Source: Elaborated by the authors.

\section{DISCUSSION}

\subsection{The notion of fit: moderation of the role-mix by market dynamism}

In order to open up the black box of the company, the focus of this study was the relationship between external market dynamism and the internal role-mix, and firm capabilities by the moderated effects on performance. The research question was: will companies perform better, when there is a fit between the environment and the employee role-mix, and are firm capabilities indifferent to the environment? To answer this question, we measured the effects of the role-mix and knowledge related firm capabilities moderated by market dynamism. Using a multi-level analysis, we controlled for company influences.

Concerning the Internal Process versus Open System orientation, management literature puts forward that dynamic situations require flexible behaviors (Jansen et al., 2009; Ketkar \& Sett, 2010; Mintzberg et al., 1998; Quinn et al., 1990). Ecologic literature puts more attention to the limited 
tolerance range of inflexible types and the wide tolerance range of roles with flexible behaviors (Mackenzie et al., 1998). The results of the present study (Table 5.1.1) are in line with this ecologic literature, showing that, when dynamism increases, the contribution of the Internal Process roles (consolidation and coordination behavior) is restricted. The contribution of the Open System roles (flexible behavior) stays the same; Open System roles contribute in both low and high dynamic situations.

A positive influence of market dynamism on the axis of Human Relations Rational Goal is shown in Table 5.1.1. Without the influence of market dynamism, Rational Goal and Human Relations are not significant. This is not in line with Quinn's (1990) statement that all roles are needed. However, moderated by dynamism, both roles augment their contribution: Rational Goal $(.15, \mathrm{p}<.1)$ and Human Relations (.11, p = 0,13). Probably, in stable conditions, these roles are thought to be normal, but when dynamism augments, the contribution of Rational Goal roles improves significantly, and, albeit a best linear unbiased estimate, the Human Relations roles become more important as well (Gratton, 2000).

These conclusions might help to bear our expectations. In fact, in times when dynamism increases, Internal Process roles will step on the brake too much, while in easier times they can help fine-tuning for results (Jansen et al., 2009). However, management practice often does not act according to this logic: when dynamism increases, the management reflex often is a bigger need for control, which following the present study is counterproductive. Also noteworthy is the constant contribution of Open System roles. One might say that Open System roles will have the same impact in situations with high dynamism as in situations when dynamism is low. Interestingly, this is contradictory to common wisdom that more innovation is needed in dynamic times. In fact, it seems constantly needed. Innovative and flexible organizations are not the effect of more Open System roles, but of less control.

Concerning Rational Goal roles, the related competences become more important in dynamic times, to occupy niches quick and with enough mass (Quinn et al., 1990), like in pioneer ecosystems (Begon et al., 1996). Our results also show a latent effect that human relations roles become more important in dynamic contexts, to enhance organizational flexibility and resilience (Cooper et al., 2014; Ketkar \& Sett, 2010; Lengnick-Hall et al., 2011). The main goal of HRM in dynamic contexts might be to reinforce the organizational system. The weaker moderation effect is probably because it is a derivative, or is this role too internal oriented staying in a non-fit state? Further research is required to answer this question. Management literature 
often focuses on organizational capabilities and leadership behaviors, and pays less attention the role-mix and employeeship. The present study shows, that for the role-mix, the combination of less control, more goal orientation, and constant innovation and attention to human relations could be the better mix for strategic fit in dynamic situations.

We focused our research on profit as outcome variable, but we also took the variables people (societal) and planet as outcome into account. The results are less clear, maybe because of the inter observer variability. However, the same tendencies as with profit can be seen for People (societal) as performance indicator. The difference is that the intercept has a nonsignificant, but high estimate. Societal goals and results seem to be perceived as important, but the impact is company specific. This might be interesting for further research. Concerning Planet as performance indicator, no relationship could be found. Is environmental performance really as important as managers want us to believe, or is Planet still lagging in the company practice or in the respondents' perception? Or do these performance indicators require different business models and leadership styles, compared to profit maximizing models? These require additional research where values, business models and leadership models are incorporated.

\subsection{Outside-in, inside-out, or...}

How does this paper contribute to the debate between positioning school and RBV? Authors call for models dealing simultaneously with market and resources (Armstrong \& Shimizu, 2007; Hamel, 2009; Priem \& Butler, 2001b). The Ecologic System Model (Section 2, Figure 2.1) is such a model, showing three alternative starting points for the strategy process: counter clockwise the outside-in process starting at market dynamism, clockwise the inside-out process starting with employee roles and capabilities as resources, and clockwise an adaptive process starting at the connection between market dynamism and employee roles. The present study shows that the second alternative, the inside-out process with knowledge related firm capabilities as the explaining factor, is substantial and highly significant (Table 5.2.1): the system is resilient enough to cope with market dynamism, while the proportion of the individual roles in the role-mix adapt.

However, the positioning school strategists might say that the performancemarket relation is an indirect relation via the process of strategy formulation. For example, it is claimed that strategic performance measurement systems contribute to strategy formulation and help to surpass the strategy-to- 
performance gap (Gimbert, Bisbe, \& Mendoza, 2010; Koufteros, Verghese, \& Lucianetti, 2014). However, this is not the case when environmental dynamism is high (Bisbe \& Malagueño, 2012). The present study indicates that the resource-based approach complemented with an employee-market connection is suited when dynamism is increasing.

Only for societal performance the moderating influence on capabilities seems present, with a substantial negative best linear unbiased estimate $(-0,8 \mathrm{p}=0,16)$. This probably means that for societal goals, market dynamism is a hindrance. When market dynamism increases, societal goals get a lower priority.

\section{FINAL CONSIDERATIONS}

Above we have argued that the results of the present study support a clockwise direction. This has consequences for the ideas about change management. When change is managed counter clockwise, management formulates the reason for change. In a clockwise direction the influence of market dynamism directly gives the reason for change. In other words: is change deliberate with achievable goals, or is it emergent, like development and succession of ecosystems?

Also leadership style might be important in the process of achieving strategic fit (Peterson, 2009), which can be enhanced by the adaptation of the role-mix appropriate to the environment. Further research into the relation between leadership style and adaptation of the role-mix is recommended. The contribution of the present study is, complementary to the RBV, the concept of employee-market connection as a starting point for adaptation and development of the organization.

\section{O AJUSTE ENTRE OS PAPÉIS DOS FUNCIONÁRIOS E O DINAMISMO DO MERCADO: UMA PERSPECTIVA DE GERENCIAMENTO ECOLÓGICO}

\section{RESUMO}

Objetivo: Explorar o ajuste dos papéis dos funcionários e o dinamismo do mercado, relacionados ao desempenho. 
Originalidade/relevância: Na ecologia, o termo "ajuste” é usado para a relação entre organismos e seu ambiente. Da mesma forma, conceitualizamos a relação entre os papéis dos funcionários e os mercados: a conexão entre o funcionário e o mercado, que pode melhorar o ajuste estratégico e o desempenho das pequenas e medias empresas (PME).

Principais aspectos metodológicos: A pesquisa empírica foi realizada em 48 PME com 221 respondentes da indústria de manufatura (53\%) e a indústria de serviços (47\%) e uma análise de modelo misto foi aplicada. Síntese dos principais resultados: A combinação de funções do funcionário é moderada pelo dinamismo do mercado: quando o dinamismo do mercado aumenta, o impacto no desempenho dos papéis internos do processo diminui e o impacto dos papéis do objetivo racionais aumenta. Os resultados enriquecem a visão baseada em recursos com a conexão funcionário-mercado: o sistema é resiliente, os papéis se adaptam. Um ajuste entre o dinamismo do mercado e os papéis dos funcionários está positivamente relacionado ao desempenho.

\section{PALAVRAS-CHAVE}

Ajuste estratégico. Visão baseada em recursos. Dinamismo do mercado. Papéis dos funcionários. Inovação.

\section{REFERENCES}

Ansoff, I. (1957). Strategies for diversification. Harvard Business Review, 35(5), 113-124.

Armstrong, C. E., \& Shimizu, K. (2007). A review of approaches to emperical research on the resource-based view of the firm. Journal of Management, 33(6), 959-986. doi:10.1177/0149206307307645

Ashby, W. R. (1956). An introduction to cybernetics. London: Chapman and Hall.

Avolio, B. V., Bass, B. M., \& Jung, D. I. (1999). Re-examining the components of transformational and transactional leadership using the Multifactor Leadership Questionnaire. Journal of occupational and organizational psychology, 72 (4), 441-462. doi:10.1348/096317999166789 
Barney, J. (1991). Firm resources and sustained competitive advantage. Journal of Management, 17(1), 99-120.

Barney, J. (2001). Is the resource-based "view" a useful perspective for strategic management research? Yes. Academy of management review, 26(1), 41-56.

Bass, B. M. (1985). Leadership and performance beyond expectations. New York: Free Press.

Begon, M., Harper, J. L., \& Townsend, C. R. (1996). Ecology: Individuals, Populations and Communities ( $3^{\text {rd }}$ ed.). Oxford: Blackwell Science Ltd.

Benner, M., \& Tushman, M. L. (2003). Exploitation, exploration, and process management: The productivity dilemma revisited. Acadamy Of Management Review, 28, 238-256. doi:10.5465/AMR.2003.9416096

Bisbe, J., \& Malagueño, R. (2012). Using strategic performance measurement systems for strategy formulation: Does it work in dynamic environments? Management Accounting Research, 23(4), 296-311. doi:10.1016/j.mar.2012. 05.002

Brundtland, G. H. (1987). Our Common Future. Oxford University Press: World Commission on Environment and Development.

Cameron, K. S., \& Quinn, R. E. (2011). Diagnosing and Changing Organizational Culture, based on the competing values framework. San Fancisco: Jossey-Bass.

Castells, M., Himanen, P. (2002). The information society and the welfare state; the Finnish model. Oxford: Oxford University Press.

Cooper, G. L., Liu, Y., \& Tarba, S. Y. (2014). Resilience, HRM practices and impact on organizational performance and employee well-being. The International Journal of Human Resource Management, 25(17), 2466-2471. doi:10.1080/09585192.2014.926688

Crielaard, J. P. (2008). Innovation and sustainability: Create the innovative organisation Paper presented at the 8th International Conference on Management in AgriFood Chains and Networks, Ede.

Cyert, R., \& March, J. (1963). Behavioural Theory of the Firm. Oxford: Blackwell. Dess, G. G., \& Beard, D. W. (1984). Dimensions of organizational task environments. Administrative Science Quarterly, 29(1), 52-73. doi:10.2307/ 2393080

Field, A. (2009). Discovering Statistics Using SPSS (3rd ed.). London: SAGE Publications Ltd.

Gimbert, X., Bisbe, J., \& Mendoza, X. (2010). The role of performance measurement systems in strategy formulation processes. Long Range Planning, 43(4), 477-497. doi:10.1016/j.1rp.2010.01.001 
Global Reporting Initiative. (2011). Sustainability reporting guidelines: 2000-2006. Amsterdam: Global Reporting Initiative.

Grant, R. M. (1996). Prospering in dynamically-competitive environments: Organizational capbility as knowledge integration. Organization Science, 7(4), 375-387. doi:10.1287/orsc.7.4.375

Gratton, L. (2000). Living strategy: Putting people at the heart of corporate purpose. London: Pearson Education Limited.

Gunderson, L. H., \& Holling, C. S. (2002). Panarchy: Understanding transformations in human and natural systems. Washington, DC: Island Press.

Hamel, G. (2009). Moon shots for management. Harvard Business Review, $87(2), 91$.

Hamel, G., \& Prahalad, C. K. (1994). Competing for the Future. Boston: Harvard Business School Press.

Hannah, S. T., \& Lester, P. B. (2009). A multilevel approach to building and leading learning organizations. The Leadership Quarterly, 20(34-48). doi:10.1016/j.leaqua.2008.11.003

Holling, C. S. (1973). Resilience and stability of ecological systems. Annual Rev Ecological Systems, 4(1), 1-23.

Jansen, J. J. P., Vera, D., \& Crossan, M. (2009). Strategic leadership for exploration and exploitation: The moderating role of environmental dynamism. The Leadership Quarterly, 14(1), 5-18. doi:10.1016/j.leaqua.2008.11.008

Kalliath, T. J., Bluedorn, A. C., \& Gillespie, D. F. (1999). A Confirmatory factor analysis of the competing values instrument. Educational and Psychological Measurement, 59(1), 143-158. doi:10.1177/0013164499591010

Ketkar, S., \& Sett, P. K. (2010). Environmental dynamism, human resource flexibility, and firm performance: Analysis of a multi-level causal model. The International Journal of Human Resource Management, 21 (8), 1173-1206. doi:10.1080/09585192.2010.483841

König, B., Diehl, K., Tscherning, K., \& Helming, K. (2013). A framework for structuring interdisciplinary research management. Research Policy, 42(1), 261-272. doi:10.1016/j.respol.2012.05.006

Koufteros, X., Verghese, A., \& Lucianetti, L. (2014). The effect of performance measurement systems on firm performance: A cross-sectional and a longitudinal study. Journal of Operations Management, 32(6), 313-336. doi:10.1016/j.jom.2014.06.003

Kraaijenbrink, J., Spender, J. C., \& Groen, A. J. (2010). The resource-based view: A review and assessment of its critiques. Journal of Management, 36(1), 349-372. doi:10.1177/0149206309350775 
Lawrence, \& Lorsch, J. W. (1967). Organization and environment: Managing differentiation and integration. Boston: Harvard University.

Lawrence, K. A., Lenk, P., \& Quinn, R. E. (2009). Behavioral complexity in leadership: The psychometric properties of a new instrument to measure behavioral repertoire. The Leadership Quarterly, 20(2), 87-102. doi:10.1016/j. leaqua.2009.01.014

Lengnick-Hall, C. A., Beck, T. A., \& Lengnick-Hall, M. L. (2011). Developing a capacity for organizational resilience through strategic human resource management. Human Reource Management Review, 21 (3), 243-255. doi:10. 1016/j.hrmr.2010.07.001

Luo, Y., \& Peng, M. W. (1999). Learning to compete in a transition economy: Experience, environment, and performance. Journal of International Business Studies, 30(2), 269-295. doi:10.1057/palgrave.jibs. 8490070

Mackenzie, A., Ball, A. S., \& Virdee, S. R. (1998). Instant Notes in Ecology. Oxford: Bios Scientific Publishers.

March, J. G. (1991). Exploration and exploitation in organizational learning. Organization Science, 2(1), 71-87. doi:10.1287/orsc.2.1.71

McWilliams, A., \& Siegel, D. S. (2011). Creating and capturing value: Strategic corporate social responsibility, resource base theory, and sustainable competitive advantage. Journal of Management, 37(5), 14801495. doi:10.1177/0149206310385696

Mintzberg, H. (1983). Structure in fives: Designing effective organizations. Englewood Cliffs, NJ: Prentice Hall.

Mintzberg, H., Ahlstrand, B., \& Lampel, J. (1998). Strategy safari: A guided tour through the wilds of strategic management. New Jersey: Prentice Hall.

Newbert, S. L. (2008). Value, rareness, competitive advantage, and performance: A Conceptual-level empirical investigation of the resource-based view of the firm. Strategic Management Journal, 29(7), 745-768. doi:10.1002/smj.686

Nonaka, I., \& Von Krogh, G. (2009). Tacit knowledge and knowledge conversion: Controversy and advancement in organizational knowledge creation theory. Organization Science, 20(3), 635-652. doi:10.1287/orsc. 1080.0412

Ohmae, K. (1982). The mind of the strategist: McGraw-Hill Inc.

Parnell, J. A. (2008). Sustainable stategic management: Construct, parameters, research directions. International Journal Sustainable Strategic Management, 1(1). doi:10.1504/IJSSM.2008.018125 
Patterson, M. G., West, M. A., Shackleton, V. J., Dawson, J. F., Lawthom, R., Maitlis, S.,... Wallace, A. M. (2005). Validating the organizational climate measure: Links to managerial practices, productivity and innovation. Journal of Organizational Behavior, 26(4), 379-408. doi:10.1002/job.312

Peterson, H. C. (2009). Transformational supply chains and the 'wicked problem' of sustainability: Aligning knowledge, innovation, entrepreneurship, and leadership. Journal on Chain and Network Science, 9(2), 71-82. doi:10.3920/JCNS2009.x178

Pfeffer, J. (1998). The human equation: Building profits by putting people first. Boston, MA: Harvard Business School Press.

Porter, M. E. (1985). Competitive advantage: Creating and sustaining superior performance. New York: Free Press.

Porter, M. E. (2008, January). The five competitive forces that shape strategy. Harvard Business Review, 24-40.

Priem, R. L., \& Butler, J. E. (2001a). Is the resource-based "view" a useful perspective for strategic management research? Acadamy Of Management Review, 26, 22-40. doi:10.5465/AMR.2001.4011928

Priem, R. L., \& Butler, J. E. (2001b). Tautology in the resource-based view and the implications of externally determined resource value: further comment. Acadamy of Management Review, 26(1), 57-66. doi:10.5465/ AMR.2001.4011946

Quinn, R. E., Faerman, S., Thompson, M., \& McGrath, M. (1990). Becoming a master manager: A competency based framework. New York: John Wiley.

Quinn, R. E., \& Rohrbaugh, J. (1983). Spatial model of effectiveness criteria: Towards a competing values approach to organizational analysis. Management Science, 29(3), 363-377.

Raisch, S., \& Birkinshaw, J. (2008). Organizational ambidexterity: Antecedents, Outcomes, and moderators. Journal of Management, 34(3), 375-409. doi:10. 1287/orsc. 1090.0428

Stalk, G., Evans, P., \& Shulman, L. (1992, May/June). Competing on capabilities: The New rules of corporate strategy. Harvard Business Review, 79-91.

Stearns, S. C., \& Hoekstra, R. F. (2005). Evolution: An introduction (2nd ed.). Oxford: Oxford University Press.

Teece, D. J., Pisano, G., \& Shuen, A. (1997). Dynamic Capabilities and Strategic Management. Strategic Management Journal, 18(7), 509-533.

Townsend, C. R., Harper, J. L., \& Begon, M. (2000). Essentials of ecology. Malden, Massachusetts: Blackwell Science Inc. 
Treacy, M., \& Wiersema, F. D. (1995). The discipline of market leaders: Choose your customers, narrow your focus, dominate your market. London: Harper Collins.

Venkatraman, N. (1989). The concept of fit in strategy research: Toward verbal and statistical correspondence. Acadamy of Management Review, 14(3), 423-444.

Verkerk, M. J. (2004). Trust and power on the shop floor: An ethnographical, ethical, and philosophical study on responsible behaviour in industrial organisations. Delft: Eburon Academic Publishers.

Volberda, H. W. (1992). Organizational flexibility: Change and preservation. Groningen: Wolters-Noordhoff.

Wernerfelt, B. (1984). A resource-based view of the firm. Strategic Management Journal, 5(April-June), 171-180.

Williams, J. R. (1998). Renewable advantage: Crafting strategy through economic time. New York: The Free Press.

Williamson, O. E. (1979). Transaction-cost economics: The governance of contractual relations. Journal of Law Economics, 22 (233-261).

Witteloostuijn, A. v. (1998). Bridging behavioral and economic theories of decline: Organizational inertia, strategic competition, and chronic failure. Management Science, 44(4), 501-519.

\section{(APPENDIX)}

(Appendix 1)

RESEARCH VARIABLES: DEFINITION, MEAN, STANDARD DEVIATION, CRONBACH $\alpha$ AND QUESTIONS

\begin{tabular}{|c|c|c|c|c|}
\hline Variables & Operational definitions and indicators & Mean & SD & Cronb $\alpha$ \\
\hline Company & Unit of analysis is an independent operating unit. & & & \\
\hline $\begin{array}{l}\text { Market } \\
\text { dynamism }\end{array}$ & $\begin{array}{l}\text { Exposure to the unpredictability of the market. } \\
\text { 1. Our clients are capricious and/or make hard } \\
\text { unilateral demands. } \\
\text { 2. In this market segment (the requirements of) } \\
\text { our clients and partners are unpredictable. }\end{array}$ & 3.8032 & 1.2936 & $\alpha=.69$ \\
\hline
\end{tabular}

(continue) 


\section{(Appendix I (conclusion))}

\section{RESEARCH VARIABLES: DEFINITION, MEAN, STANDARD DEVIATION, CRONBACH $\alpha$ AND QUESTIONS}

\begin{tabular}{|c|c|c|c|c|}
\hline Variables & Operational definitions and indicators & Mean & SD & Cronb $\alpha$ \\
\hline Employee roles & $\begin{array}{l}\text { A behavior pattern with associated competences } \\
\text { (qualities of people) to fulfill the demands of the } \\
\text { market. }\end{array}$ & & & \\
\hline Open system & $\begin{array}{l}\text { Roles and competences oriented at adaptation, } \\
\text { and external support in changing circumstances } \\
\text { by flexibility, creativity, and innovation. }\end{array}$ & 4.4491 & 91699 & $\alpha=.87$ \\
\hline Rational goal & $\begin{array}{l}\text { Roles and competences oriented at productivity } \\
\text { and profit maximization by analysis, direction } \\
\text { and action. }\end{array}$ & 4.5599 & .93657 & $\alpha=.91$ \\
\hline Internal process & $\begin{array}{l}\text { Roles and competences oriented at stability and } \\
\text { continuity by description and control of routines. }\end{array}$ & 4.2926 & 94647 & $\alpha=.76$ \\
\hline Human relations & $\begin{array}{l}\text { Roles and competences oriented at commitment, } \\
\text { cohesion and morale by participation, solving } \\
\text { conflicts and consensus. }\end{array}$ & 4.7734 & .95509 & $\alpha=.83$ \\
\hline $\begin{array}{l}\text { Knowledge } \\
\text { related firm } \\
\text { capability }\end{array}$ & $\begin{array}{l}\text { The firm's ability to perform a productive task. } \\
\text { Here, restricted to knowledge and innovativeness. }\end{array}$ & 4.2513 & .80952 & $\alpha=.74$ \\
\hline $\begin{array}{l}\text { Performance } \\
\text { indicators }\end{array}$ & $\begin{array}{l}\text { Outcome or effects. } 3 \text { outcome variables, } 1 \text { - } 4 \\
\text { questions each, using 7-point Likert scales } \\
\text { ranging from strongly disagree to strongly agree. }\end{array}$ & & & \\
\hline 3P-performance & The combination of Profit, Planet and People & 4.1219 & .90466 & $\alpha=.79$ \\
\hline Profit & Perception of growth in profit and turnover. & 4.9539 & 1.2838 & $\alpha=.78$ \\
\hline Planet & $\begin{array}{l}\text { Perception of results in input (resources, energy, } \\
\text { water), emissions (air pollution, waste, waste- } \\
\text { water), and environment (biodiversity and areas). }\end{array}$ & 3.6171 & 1.2603 & $\alpha=.85$ \\
\hline People (societal) & $\begin{array}{l}\text { Perception of societal contribution: investments; } \\
\text { labor, training and education; health, diversity and } \\
\text { participation). }\end{array}$ & 4.0398 & 1.0835 & $\alpha=.76$ \\
\hline
\end{tabular}

Source: Elaborated by the authors.

Means on a 7-point Likert scale, ranging from 1 to 7. 


\section{(Appendix 2) \\ QUESTIONNAIRE}

All questions to be answered on a Likert scale from 1-7.

\section{Market dynamism}

1 Our clients are capricious and/or make hard unilateral demands.

2 In this market segment (the requirements of) our clients and partners are unpredictable.

\section{Employee roles}

If you look at colleagues (managers and co-operators) in your organisation, how often do they:

Open System roles:

3 Contribute to inventive ideas.

4 Influence superiors in the organisation.

5 Look for innovation and potential improvements.

6 Experiment with new concepts and procedures.

7 Communicate with people in higher positions.

8 Solve problems in a creative, clear way.

9 Convincingly sell new ideas to superiors.

10 Influence decisions taken at a higher level.

Internal Process roles:

11 Keep tight control of the logistics.

12 Know what is happening in the department.

13 Maintain coordination and documentation of the department.

14 Ensure that people stick to the rules.

15 Compare minutes, reports, etc. to uncover any contradictions.

16 Solve roster problems in the department.

17 Anticipate problems in the flow of work and avoid a crisis.

18 Check for errors and mistakes.

19 Create an atmosphere of order and coordination within the department. 
Rational Goal roles:

20 Clarify the necessity to achieve department goals.

21 Constantly clarify the department's goal.

22 Very clearly describe the department's role.

23 Encourage the department to achieve goals.

24 Try to improve the technical capacity of the work group.

25 Let the department achieve the expected goals.

26 Ensure that the department meets the agreed goals on time.

27 Clearly set the priorities and the work direction of the department.

28 Keep the department focused on the result.

29 Regularly clarify the department's objectives.

Human relations roles:

30 Look for mutually accepted solutions for open differences of opinion.

31 Listen to private problems of employees.

32 Keep open discussions about opposing opinions in the group.

33 Reveal the core differences between group members and then actively contribute to solving them.

34 Treat every employee with sensitivity and care.

35 Show interest and involvement in dealings with employees.

36 Encourage participation in decision-making in the group.

37 Facilitate consensus within the department.

38 Show concern for the welfare of your employees.

\section{Knowledge related firm capabilities}

39 We get more clients because of knowledge exchange.

40 Every co-operator is acquainted with the company's knowledge.

41 Every co-operator knows exactly the topics on the existing and potential market.

42 The percentage co-operators with excellent competences for the job augments.

43 We are perceived as having authority, and leading in knowledge in our domain.

44 We have a reputation for being the most innovative company in our sector. 


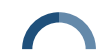

Jack P. Crielaard, Emiel F. M. Wubben, Onno S. W. F. Omta

\section{Performance: profit}

45 We have really achieved our goals in turnover or budget.

46 We have really achieved profit targets. (ebit)

\section{Performance: planet}

47 We have really achieved desired results in resources, energy or water.

48 We have really achieved desired results in the reduction of emissions (air pollution, waste water, waste).

49 We have really achieved desired results in biodiversity and environment.

\section{Performance: people (societal)}

50 We have really achieved desired results in social investments.

51 We have really achieved results in employment, training and education.

52 We have really achieved results in health, diversity and participation.

\section{) AUTHOR NOTE}

Jack P. Crielaard, Graduate School of Science, University of Amsterdam, ORCID:0000-00034157-8717; Emiel F. M. Wubben, Erasmus Schools of Economics, Erasmus University Rotterdam, ORCID:0000-0002-3287-1076; and Onno S.W.F. Omta, University of Groningen, ORCID:00000002-4237-4305.

Emiel F. M. Wubben is now an Associate Professor of Strategic Management at Wageningen University.

Correspondence concerning this article should be addressed to Emiel F. M. Wubben, Hollandseweg 1, 6706KN, Wageningen, Guéldria, The Netherlands.

E-mail: emiel.wubben@wur.nl

EDITORIAL BOARD

Editor-in-chief

Silvio Popadiuk

Associated Editor

Silvio Popadiuk

Technical Support

Vitória Batista Santos Silva
EDITORIAL PRODUCTION

Publishing Coordination
Irina Migliari
Editorial Trainee
Maria Luiza Vanz
Copyeditor
Irina Migliari

Language Editor

Daniel Leão

Layout Designer

Emap

Graphic Designer Libro 